\title{
Factors affecting Customer Loyalty in Banking Sector: A study on Banks in Bahawalpur (Pakistan)
}

\author{
Hafiz Muhammad Wasif Rasheed, Muhammad Sajid, Naeem Shahid, Mehboob Ahmad, \\ Research Scholars, Department of Management Sciences \\ The Islamia University of Bahwalpur, Pakistan
}

Junaid Khalid*, Hafiz Muhammad Usman Khizar, Waseem Ahmad Khan

Lecturers, Department of Management Sciences, The Islamia University of Bahawalpur

\author{
Accepted: May 07, 2015
}

DOI: 10.5296/ijafr.v5i1.7726 URL: http://dx.doi.org/10.5296/ ijafr.v5i1.7726

\begin{abstract}
The emergence of new banking channels like as phone banking, Internet banking, Automated Teller Machines (ATM), furthermore developing financial market \& global competition have constrained bankers to explore the importance of customer loyalty. For the banks to be successful in the intensively competitive environment, they are bound to attach importance to customer loyalty. The aim of this study is to investigate how the behavior and intentions of the respondents will be influenced by different factors of customer loyalty. The objectives of the current study are of two folds; firstly, to examine the relationship of trust, customer satisfaction and service quality with customer loyalty. Secondly, to determine which factor influenced customer loyalty the most? Data was collected through non probability convenience sampling, from a sample of 496 respondents by using a self-administered questionnaire. The collected Data was analyzed through regression technique using SPSS 17. Results of the current study reveal that trust, customer satisfaction and service quality has significant effect on customer loyalty. But the relationship or trust with customer satisfaction is not proved. Moreover the study revealed that customer satisfaction is found as the most influential variable for customer loyalty. The managerial implication of this research is the considerations of bank managers for the enhancement of their customer loyalty.
\end{abstract}

Keywords: Customer Loyalty, Customer Satisfaction, Service Quality, Trust and Banks. 


\section{MInstitute ${ }^{\text {Mink }}$}

International Journal of Accounting and Financial Reporting

ISSN 2162-3082

2015, Vol. 5, No. 1

\section{Introduction}

Oliver (1999) has described loyalty as a deeply held commitment to rebuy or re-patronize a preferred product/service consistently in the future. Customer loyalty can be achieved by identifying the customer needs, managing them and by fulfilling them (Maikayi et-al,2011). It is actually considered as a combination of customer's favorable attitudes and their repurchase behaviors. Customer loyalty is point of convergence for various business associations and the accomplishment of organization deals are guaranteed by Customer loyalty, which can be affected by administration activity (Gerpott Rams \& Schindler, 2001).

Customer loyalty has been a real concern in banking to professionals because of serious rivalry and higher client expectations. Customer loyalty is viewed as a key connection and desire to hierarchical achievement, benefit and business execution (Oliver, 1997; Reichheld, 1993; Sheth and Parvatiyar, 1995). The customers that demonstrate the best levels of reliability at the item, or service action, have a tendency to repurchase all the more regularly, and spend more cash. In this way, loyal customers don't just build the estimation of the business, additionally empower business to keep up expenses lower than those connected with attracting new clients (Barroso and Martin, 1999). Shoemaker and Lewis (1999) stated that marketing has shifted from customer acquisition to customer retention and loyalty. In addition Mcllory and Barnet (2000) state that to get new customer is five times costly to maintain existing customers. Loyal customers will always give positive comments and recommendations about the company to others. Firms can maximize level of profitability by providing safe and sound products and services to loyal customers.

One of the approaches to upgrade customer loyalty in managing an account is by concentrating on offering amazing services and fulfills the needs of client. Banks need to have a decent understanding of their client behavior so proper marketing strategies guided towards relationship building and client maintenance can be created. The traditional product-oriented bank is becoming increasingly customer-oriented in accordance with the basic principles of relational marketing, which focuses on customer loyalty. Loyalty to a bank can be thought of as continuing patronage over time. The degree of loyalty can be gauged by tracking customer accounts, over defined time periods and noting the degree of continuity in patronage (Yi \& Jeon, 2003). In order to increase customer loyalty, many banks have introduced innovative products and services (Alam \& Khokhar, 2006). Country's population and the increased demand for banking services; , service quality and customer satisfaction are going to be key differentiators for each bank's future success.

Positioning is an attempt to distinguish the bank from its competitors along real dimensions in order to be the most preferred bank for a certain market segment or in other words, if a bank can position itself favorably within a particular marketplace, relative to competitors, that bank is a competitive one. Competitiveness means that a bank, in terms of its competitive position, its management and marketing strategies, its use of information technology, the quality of its products/services and its ability of managing long term customer relationship must be increasingly responsive to the market consideration and customer orientation.

Today's world of intensive competition requires firms to keep up the capacity of brilliant quality service and maintainable aggressive need. Excellent quality service suppliers will 


\section{MInstitute Macrothink $_{\text {Int }}$}

International Journal of Accounting and Financial Reporting ISSN 2162-3082

fulfill clients leading them to end up loyal customers. In greater part of researches, service quality has a critical impact on consumer loyalty (Cronin and Taylor 1992, Taylor and Baker 1994). Bloemer, Ruyter and Wetzels (1998) and Aydin \& Ozer (2005) demanded that service quality is one of the key drivers to build the loyal customers. An immediate relationship exists between servequal \& satisfaction of the client. It has been recommended that improved the service quality means satisfied the customer. Quality is a trait on which satisfaction is based (Maiyaki et al., 2011). Higher quality of service more the satisfied client will be and more prominent will be the service quality. So we can say that there exists an immediate relationship in between quality \& customer loyalty.

Customer satisfaction has become the center of service marketing and operations management because it is general proposition to be a significant antecedent of customer retention and repeat sales by positive word of mouth. Customer satisfaction is described as satisfying one's desires or meeting one's criteria or we can say that delighted / satisfied customers have specific feeling or mentality towards a product or service it has utilized (Maikayi et al., 2011). Consumer loyalty has positive impact on monetary execution of the associations and in making loyal clients. There is a positive immediate, relationship between service / product quality, customer satisfaction and consumer loyalty (Ali et al., 2010). Higher consumer loyalty is straightforwardly related in keeping up a loyal customer.

Trust is an important factor in affecting relationship commitment and customer loyalty. If one party trusts another, such a party is willing to develop a positive behavioral intention toward the other party. Accordingly, when a customer trusts a business or brand, that customer is willing to form a positive buying intention towards the business. The relationship between customer trust and customer loyalty is supported by reciprocal arguments. When service providers act in a way that builds customer trust, the perceived risk with the service provider is reduced, thus enabling the customer to make confident predictions about the service provider's future dealings. Trust influences loyalty by affecting the customer's perception of congruence in values with the service provider, and such value congruence is significantly related to the customer's satisfaction and loyalty. Trust as an element of customer loyalty has an influence on building customer loyalty (Aydin \& Ozer 2005: 146; Chen \& Xie 2007: 64; Du Plessis 2010: 91-92). The development of trust is further considered an important result of investingin a dyadic and affective relationship between the parties in the relationship. Increased trust is cited as critical for relationship success between the customer and the business (Huang \& Chiu 2006: 157).

\section{Literature Review}

\subsection{Customer Loyalty}

Customer loyalty is unique sort of client attitude towards the association. It is somewhat future forecast about the intentions of the client to work with the firm (Zeithaml, Berry, \& Parasuraman, 1996). It is the general attitude of client in regards to service, product or some other aspect of the association in which client is included, makes the term client loyalty (Oliver, 1999). Clients loyalty built practices are indigent in light of various components. On the off chance that organizations need to advance the dependability practices of client, they must adjust and oversee different aspects of client experience (Prof. gopalkrishnan et al., 
2011).

Loyalty has been a primary concern in marketing planning for different reasons including global competition, market saturation, technological development, and customer awareness. In fact, a long-term success is not just a function of fair price but it is a function of quality of products and services and many corporations prefer to build a long-term relationship with their customers using customer oriented preferences. To finish the target of getting and holding a bigger number of clients, all the organizations ought to underline on building client loyalty by maximizing the share of clients. Henceforth building client loyalty ought to be viewed as an essential business strategy instead of simply a marketing program (Duffy, 1998).

Thus, it is important to increase and retain loyal customers, which may serve as a main factor in long-term success of corporations. Prior to defining customer loyalty, we have to know whether loyalty is a behavior standard or an attitude standard. Behavioral loyalty tries to describe brand loyalty based on real observed purchases in a specified time, whereas attitude loyalty standards are based on certain priorities, commitment, or intention for purchase. Attitude commitment includes a desired fixed set of specific beliefs about the purchased brand. The intensity of these attitudes is an important factor in purchasing and supporting a brand (Larsson et al., 2004). Oliver's (1997) perspective proposes that loyal customers go through four stages. First is a cognitive sense (belief). For example, sales promotion or high quality products of a firm for first- IME purchase consideration attracts a customer. To be loyal, the customer must consistently confirm that his or her expectations about the goods or services are met. Second is the affective sense (favored attitude) in which consumers are repeatedly satisfied from purchasing decisions. Third is the conative stage that consumers have a behavioral intention - committed deeply to buy. The intention leads to the fourth stage of action. Customers have the desire to overcome obstacles, e.g., attraction of competitors or price increase by a firm, to achieve the actual purchase behavior (Oliver, 1997).

Customer loyalty in today's era has been a real concern to experts because of extreme competition and high consumer desires. Customer loyalty is viewed as a basic connection and desire to organizational achievement, business performance and profit (Oliver, 1997; Reichheld, 1993; Sheth and Parvatiyar, 1995). The customers that demonstrate the best levels of dedication at the item, or administration action, have a tendency to repurchase all the more frequently, and spend more cash. In this manner, loyal customers don't just build the estimation of the business; additionally empower business to keep up expenses lower than those connected with connected new clients (Barroso and Martin, 1999). Additionally, devotion as opposed to satisfaction is turning into the most obvious key objective in today's focused business environment (Oliver, 1999).

\subsection{Customer Satisfaction}

Consumer loyalty implies that a client or the user of service is decently battled with the execution (Johnson \& Fornell, 1991). Consumer satisfaction is characterized as a client's general assessment of the performance of an offering to date (Johnson and Fornell 1991). While consumer satisfaction has been characterized in different ways, high level conceptualization that seems to have picked up the most extensive acknowledgement 
expresses that satisfaction is a client's post buy assessment of a service or product (Cronin \& Taylor, 1992; Westbrook \& Oliver, 1991). It can likewise be expressed as the general assessment of a client either negative or positive for services (Woodruff, 1997).

Effect of satisfaction on loyalty is inquired about in wide terms. Numerous discoveries show that if the customer/consumer is satisfied than they are loyal and if they are dissatisfied their loyalty is not ensured. It is utilized to clarify loyalty as behavioral purposes (Heskett et al., 1994). Thus management ought to pay unique spotlight on the customer satisfaction and for it service quality is assumes a crucial part (Akbar and Parvez et al., 2009). Satisfaction has an important characteristic which must be taken into record when shaping the general customer loyalty towards their service suppliers.

In banks, the clients get some information about the level of the services and choose about the absence of importance given to them and choose about repurchase behavior in the wake of utilizing the services. Also In banking sector, the premium rates on loans $\&$ charges on the use of online services, for example, processing fee \& ATM machines is a real bone of discord between the bank and its clients. If customers are satisfied, then loyalty infuses naturally and the current stays with the current service providers for a time (Giese \& Cote, 2000). The discoveries of consumer loyalty on profitability propose that benefit is subject to satisfaction which implies that achievable increments in satisfaction could significantly enhance profitability (Hallowell, 1996).

According to previous researches that to improve the loyalty; customer satisfaction assumes a major part and is the most imperative driver (Sondoh et al., 2007). It also shows that if the customers are satisfied then customer's loyalty automaticaly increased and henceforth customer's intention to switch banks will diminish (Hoq et al., 2010). A key inspiration for expanding the attention on consumer satisfaction is that higher consumer satisfaction can prompt have a stronger position bringing about higher profitability \& market share (Fornell, 1992).Customer satisfaction goes about as a mediator between service quality and clients repurchase propositions. With a specific end goal to get long term connections and long term advantages it is vital for association to continuously satisfied the clients so they stay to the same association and stick to it in long run and proceed with repurchase. Consumer loyalty comes after the use of some service or product which is essentially the result of real and expected capacities of product (Khokhar et al., 2011).

H1: Customer Satisfaction has significant relationship with Customer Loyalty.

\subsection{Trust}

Trust is a level of some one's confidence in another party's competence and his performance based on predictable ethical principles (Errol et al., 2005). It is defined as the willingness to rely on an exchange partner in whom one has confidence (Moorman et al. 1993) or confidence in an exchange partner's reliability and integrity (Morgan \& Hunt 2004). Chaudhuri \& Holbrook (2002) define brand trust as the customer's willingness to rely on the ability of the brand to perform its stated function. Liang and Wang (2006 states in this context that trust is "the perceived level of confidence in transaction partners' reliability and honesty". 


\section{Mll Macrothink}

International Journal of Accounting and Financial Reporting ISSN 2162-3082 2015, Vol. 5, No. 1

Trust is "the belief that a partner's word or promise is reliable and a party will fulfill his/her obligations in the relationship" (Schurr \& Ozanne, 1985). Trust is an important construct in relational exchange because relationships characterized by trust are so highly valued that parties will desire to commit themselves to such relationships (Hreinian, 1974). Creating trust in customer mind set importance for companies because from the previous studies.

Business exchange between two sides or increasingly can happen if they trusts each other. Trust can't be conceded effortlessly by other side/business accomplice; it must be built from the earliest starting point and can be demonstrated. Trust is considered as the impetuses in any transactions are occurred between buyer and seller so that the consumer satisfaction can be executed obviously. Trust is a critical precursor of loyalty (Ball et al., 2004). Trust causes devotion on the grounds that it decreases the expenses of negotiating agreements (Berry, 2007) and reduces clients' fear of opportunistic attitude by the service supplier (Bendapudi \& Berry, 1997). Honesty is the conviction that an accomplice remains by his word, while consideration is the conviction that the partner is occupied with the client's welfare, and won't bring activities with negative effect on the client.

Morgan \& Hunt (1994) additionally recommend that brand trust prompts brand loyalty and commitment in fact trust makes trade connections that are highly valued. So as to build the levels of trust, organizations must spotlight on keeping guarantees to their clients and reliably convey their best enthusiasm at heart (Hocutt, 1998).

According to Morgan and Hunt (1994), connections can be seen as a series of transactions that encourage a consciousness of an imparted relationship through commitment and trust. High trust and commitment thusly are identified with larger amounts of client retention, and that brings about higher firms profitability. According to Thomas (2009: 346) trust as "a hope of positive results, results that one can get focused around the normal activity of an another party". A key viewpoint that is reflected in this meaning of trust is validity. Credibility influences the long run introduction of a client by decreasing the view of risk associated with opportunistic attitude by the firm. Particularly, trust lessens uncertainty in an environment where clients feel powerless in light of the fact that they know they can depend on the trusted association (Aydin \& Ozer 2005: 146).

H2: Trust has significant influence on Customer Satisfaction

H3: Trust has significant influence on Customer Loyalty

\subsection{Service Quality}

Service quality can be characterized just by consumers and that it happens when a service association gives benefit that fulfills the consumer's needs (Metters et al., 2003). Basically service quality is characterized as the satisfaction of client expectations. Service quality is a complex build which has multi-aspect attributes or multi-measurements. To confirm the determinants of servequal, an extensive number of explores have been accounted for amid the last twenty five years (Lee, 2010a). Specifically, Grönroos's (1984) two-dimensional model can be described as follows: 1) technical quality is "what a customer receives," and 2) functional quality is "how a service is provided or delivered." Quality is defined as the 


\section{Mll Macrothink}

International Journal of Accounting and Financial Reporting

ISSN 2162-3082

2015, Vol. 5, No. 1

correlation between customer's desires and performance. Service quality incorporates solace, variety in packages; friendliness gave by service suppliers to their clients. Also, other theoretical and observational studies recommend that servequal is contained service environment, service product \& service delivery (Rust and Oliver, 1994) or outcome quality, physical environment quality \& interaction quality (Brady and Cronin, 2001; Lee, 2011).

Dimensions of service quality:

Products are tangible and their estimation is focused on performance, durability \& features. Service is intangible and can be measured on observation. The determinants are clarified underneath:

Reliability: The capacity to perform the guaranteed service precisely.

Responsiveness: The ability to help clients to respond absolutely.

Assurance: Ability to pass on trust and certainty to clients.

Empathy: The caring, consideration given to clients.

Tangibles: The presence of facilities, supplies, faculty and correspondence materials (Maiyaki et al., 2011).

Numerous studies have discovered an immediate positive connection between customer behavioral plans \& service quality perceptions (Boulding et al., 1993; Zeithaml et al., 1996). Cronin et al. (2000) led an experimental exploration through an extensive scale overview of six industries and reported the causal impact of service quality on behavioral intentions. Ranaweera and Neely (2003) demonstrated that there is a solid relationship between customer loyalty and service quality; that is, the higher the view of service quality, the more noteworthy the level of repurchase propositions. Therefore, benefit quality is a vital driver of client maintenance. Notwithstanding client maintenance, service quality is respected to be a basic variable in the money related yields of service firms.

Higher-quality service indicates that service quality can be defined only by customers and that it occurs when a service organization provides service that satisfies the customer's needs (Metters et al., 2003). Hence, numerous past studies uncovered that service quality can be described as a type of demeanor that is connected yet not identical to satisfaction, which comes from the comparison of expectations with performance (Parasuraman et al., 1988; Bolton and Drew, 1991; Cronin and Taylor, 1992; Lee, 2010).

H4: Higher the Service Quality higher will be the Customer Satisfaction.

H5: Higher the Service Quality higher will be the Customer Loyalty. 


\section{Macrothink

3. Model

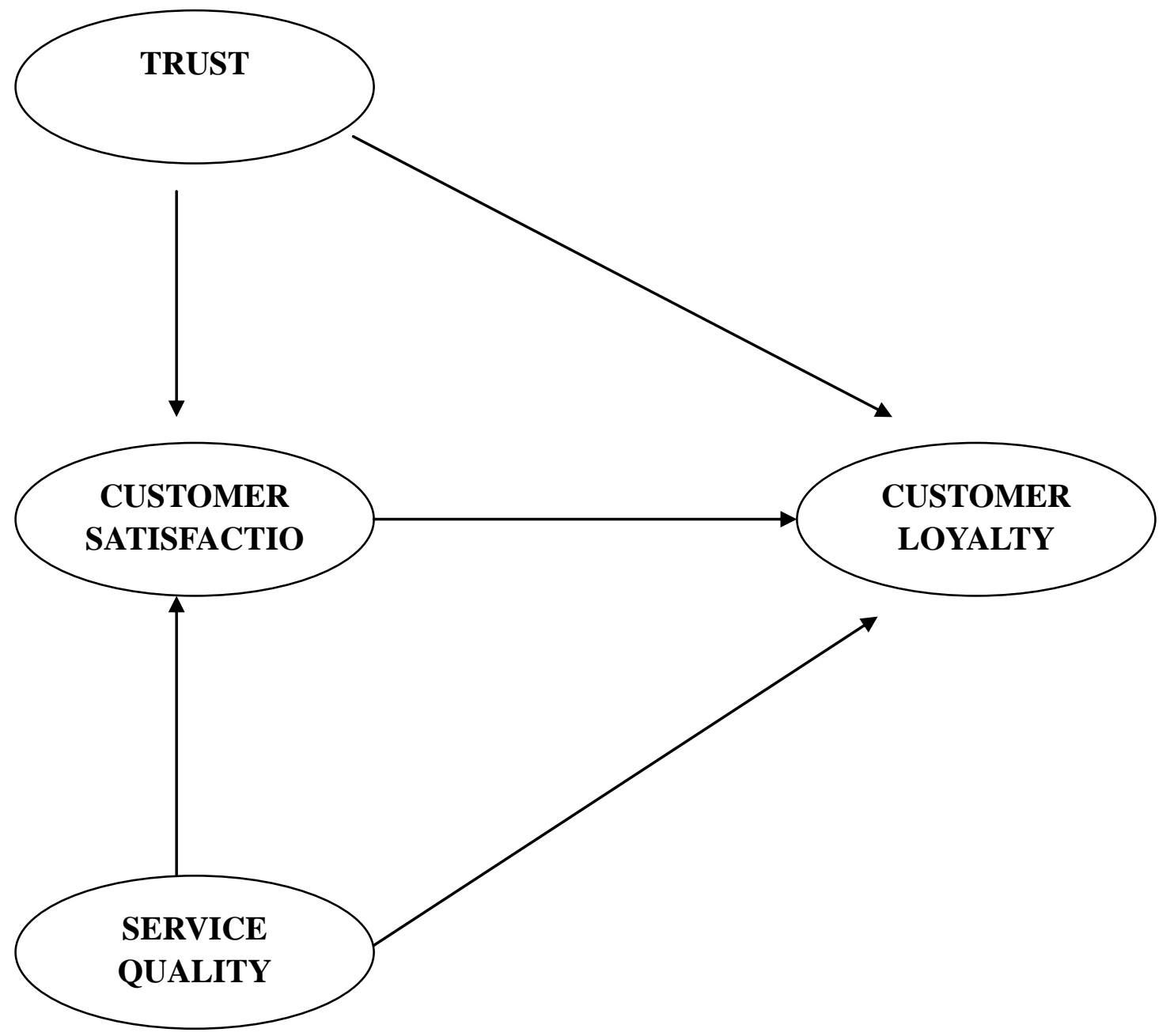

\section{Research Methodology}

This study shows the relationship of:

Customer Satisfaction with Trust and Service Quality in Banking Industry \&

Customer Loyalty with Customer Satisfaction, Trust and Service Quality in Banking Industry.

This is the causal research in which we have analyzed dependent and independent variables and checked the cause and effect relationship of independent variables on dependent variables. Customer satisfaction and customer loyalty are dependent variables whereas influencing variables discussed above are independent variables. Loyalty intention is resulted from the customer's overall satisfaction with their earlier experience from service quality and their trust. In this research it is hypothesized that the trust and service quality will influence customer satisfaction and customer loyalty, whereas customer satisfaction will have significant positive relationship with customer loyalty. 


\section{Ml Macrothink}

International Journal of Accounting and Financial Reporting

This study aims to describe how the factors of loyalty influence the customer, to be loyal to their preferred Banks. With the increase in level of awareness among customer, education level, lack of time that lead to influence the behavior of customers. Therefore, banks might be their best choice on the basis of their satisfaction, service quality and level of trust.

\subsection{Sample/Data}

For collecting data to understand the situation about loyalty of the customers, a self-administered questionnaire was prepared to record the responses. A sample of 500 respondents was given questionnaires to participate. Population for our research is customers of Banks in Bahawalpur (Pakistan). The research was conducted in those settings where participants agreed to participate in the study. Data was collected during a month in year 2013. The bank staff helped to distribute and collect the survey sheets from the participating customers. A convenience sampling method is used to collect data.

\subsection{Instrument and Measures:}

The survey instrument contains two sections. Section 1 includes different personal and demographic variables. This section obtained the respondent's information about gender, age, qualification, profession, income and with which bank they mostly made transactions. Section 2 includes the latent variables that are important in the current study. These variables include Service Quality, Trust, Customer Satisfaction and Customer Loyalty. This section of the study is developed on the past literature and already used questionnaires (Table 1).

The scales of the study were adopted from the previous literature and published studies. Data on the variables is collected using index scale, i-e using different items to measure the responses of the respondents for accounting for the sensitivity factor. Two variables naming customer satisfaction and trust have four items while customer loyalty and service quality are measured using five items.

\section{Table 1}

\begin{tabular}{|c|c|c|c|}
\hline No & Variable & Items & Reference \\
\hline $1-$ & $\begin{array}{l}\text { Customer } \\
\text { Satisfaction }\end{array}$ & $\begin{array}{l}\text { I am satisfied with the decision to choose this } \\
\text { bank } \\
\text { This bank leaves me a pleasant impression } \\
\text { I want to return to this bank in the future } \\
\text { I will advise about this bank to my friends. }\end{array}$ & $\begin{array}{l}\text { Wang et al. } \\
(2001), \text { Llosa } \\
(1996)\end{array}$ \\
\hline $2-$ & $\begin{array}{l}\text { Customer } \\
\text { Loyalty }\end{array}$ & $\begin{array}{l}\text { I regularly visit this bank } \\
\text { I seldom think of changing this bank to another } \\
\text { one } \\
\text { I use this bank each time I need to make any } \\
\text { financial transaction } \\
\text { I consider this bank as my preferred choice } \\
\text { Each time I want to make any financial }\end{array}$ & $\begin{array}{l}\text { Boulaire et } \\
\text { Mathieu (2000), } \\
\text { Srinivasan et al. } \\
\text { (2002), Huang } \\
\text { (2008). }\end{array}$ \\
\hline
\end{tabular}




\begin{tabular}{|c|c|c|c|}
\hline & & transaction, this bank is my first choice. & \\
\hline $3-$ & Trust & $\begin{array}{l}\text { This bank keeps my information confidential. } \\
\text { This bank is honest. } \\
\text { This bank is reliable. } \\
\text { This bank meets my needs. }\end{array}$ & $\begin{array}{l}\text { Hess(1995), } \\
\text { Jarvenpaa \& } \\
\text { Tractinsky } \\
\text { (1999), } \\
\text { Gurviez \& } \\
\text { Korchia (2002), } \\
\text { Gefen et al. } \\
\text { (2000), } \\
\text { Chiou \& Droge } \\
\text { (2006) }\end{array}$ \\
\hline $4-$ & $\begin{array}{l}\text { Service } \\
\text { Quality }\end{array}$ & $\begin{array}{l}\text { Ease of depositing and withdrawing money from } \\
\text { any branch } \\
\text { Continuous and ordered functionality of } \\
\text { equipment such as computer and printer etc } \\
\text { Staff takes interest in solving problem } \\
\text { Bank Maintains error free records } \\
\text { Information provided by bank employees are clear } \\
\text { and understandable. }\end{array}$ & $\begin{array}{l}\text { Adapted from } \\
\text { Jannatul Mawa } \\
\text { Nupur (2010) }\end{array}$ \\
\hline
\end{tabular}

\subsection{Procedure}

Questionnaire survey was employed as the method of data collection. The questionnaires were distributed in 5 Banks in Bahawalpur (Pakistan). Questionnaires were distributed to the customers that were willing to participate in the research, after making their transaction with their preferred banks. Purpose of the study and questions were explained to the respondents to get the relevant results. Total 496 out of 500 questionnaires were selected for further analysis while remaining questionnaires were not included due to incomplete responses. Data was analyzed using the statistical package SPSS 17.0. In order to meet the research objectives, linear regression and reliability analysis were conducted.

\subsection{Reliability Test}

Reliability test is conducted to determine the consistency of the instrument as a measuring tool, so that the result of a measurement can be trusted. Instrument is said to be reliable if the value of Cronbach's alpha is greater than 0.6 according to Moss et al. (1998) and acceptable if equal to or above 0.50 according to (Nunnally 1970). 
Table 2. Measurement of Reliability

\begin{tabular}{|l|l|l|}
\hline Scale & Items & Cronbach Alpha \\
\hline Customer Satisfaction & 4 & 0.733 \\
Customer Loyalty & 5 & 0.513 \\
Trust & 4 & 0.681 \\
Service Quality & 5 & 0.700 \\
& & \\
\hline
\end{tabular}

\section{Analysis and Results}

\subsection{Profile of the Respondents}

Personal and demographic information such as gender, age, qualification, profession and total house hold income is analyzed.

\subsection{Hypothesis Testing}

\subsubsection{Customer Satisfaction with Customer Loyalty}

Regression Analysis of the research shows that there is a significant positive relationship between Customer Satisfaction and Customer Loyalty with $(\beta=0.195)$ and $(p=0.000)$. The results validate $\mathrm{H} 1$ and suggest that the Customer Satisfaction contribute almost $20 \%$ towards Customer Loyalty.

\subsubsection{Trust with Customer Satisfaction and Customer Loyalty}

While considering the significance between the trust and Customer loyalty, the results of the current study shows that there is significant relationship between these two variables with $(\beta=0.088)$ and $(p=0.000)$ which shows that trust contribute more than $8 \%$ towards customer satisfaction. Hence validate $\mathrm{H} 3$.

The results of regression analysis shows there is no significant relationship between Trust and customer satisfaction with $(\beta=0.068)$ and $(p=0.092)$ so we reject $\mathrm{H} 2$.

\subsubsection{Service Quality with Customer Satisfaction and Customer Loyalty}

The regression results of Service Quality with Customer Satisfaction shows that there is positive and significant relationship with $(\beta=0.488)$ and $(p=0.000)$. Results also confirm that the Service Quality has a significant positive relationship with Customer Loyalty with $(\beta=0.227)$ and $(p=0.000)$ which means that Service Quality contribute $23 \%$ to Customer Loyalty. So we accept the H4 and H5.

Table 4 summarizes the regression results of the study and Figure 2 shows the graphical presentation of the structural model. 
Table 4: Regression Results

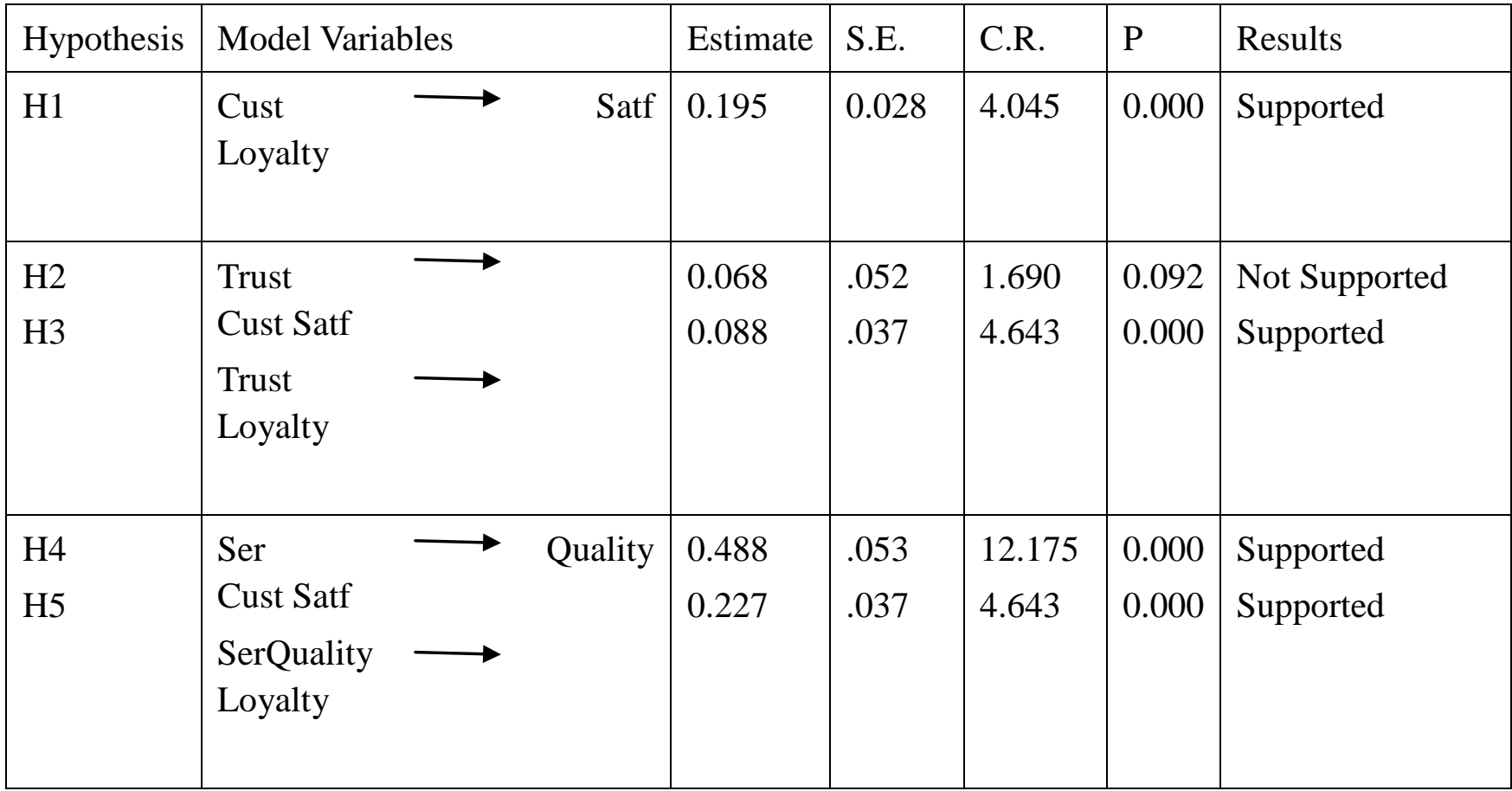

Figure 2: Structural Model Results

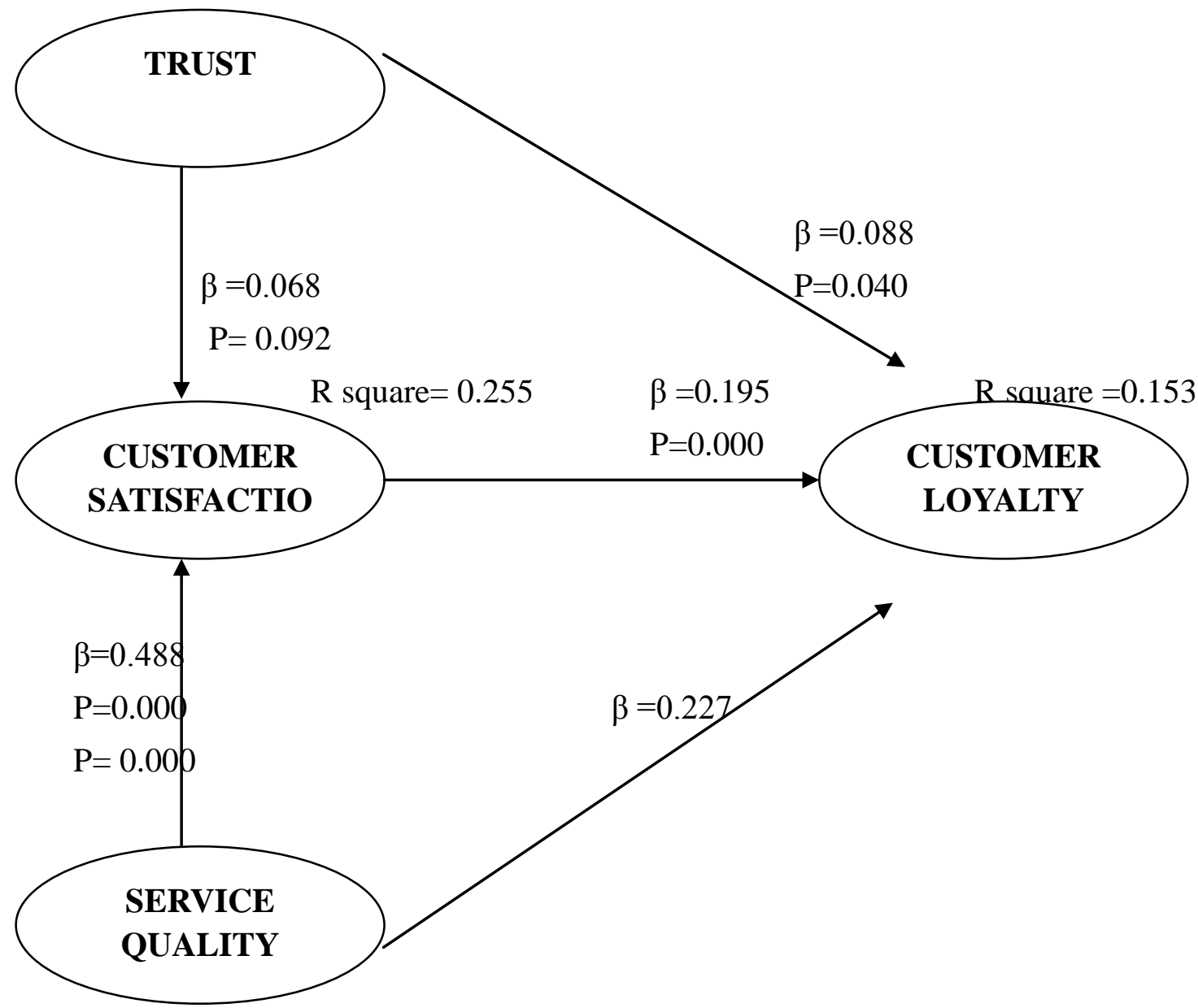




\section{Discussions}

This study aims at investigating that how respondents will be influenced by factors of customer loyalty. Throughout this research some of the objectives answered are; Firstly, to examine the relationship of trust, customer satisfaction and service quality with customer loyalty and how customer satisfaction is affected by trust and service quality. Based on regression results, it indicates that four out of five hypothesis were proved having Sig value less than 0.005 in four out of five relationships. The independent variables (trust and service quality) have positive relationship with customer satisfaction and customer loyalty, whereas relationship of trust with customer satisfaction is not proved in this research, rejecting $\mathrm{H} 2$. As value of beta shows the magnitude of the relationship between two variables and its sign shows the direction of the relationship, i-e either positive or negative, the positive relationship between the above said variables here means that the higher positive values of beta shows that how much variation in dependent variables (customer loyalty) is due to independent variables (trust, customer satisfaction and service quality). Results of our analysis have neglected the positive relationship of trust and customer satisfaction which was proved in previous researches. Analysis results shows the overall satisfaction and loyalty of the customers with their respective banks but the rejection of this hypothesis (relationship of trust with customer satisfaction) at the same time shows that customers are satisfied with their respective banks but this satisfaction is not witnessed by the facilities provided by the banks to create trust. It means that there are other factors contributing to the satisfaction of the customers other than the variables taken in this research as independent variable effecting customer satisfaction.

As discussed in literature review, the definition of customer loyalty described by different authors is 'repurchase intention and behavior of the customers towards a particular product or service'. Some of the factors contributing in re-visit decisions of the customers other than the variables discussed in our research are; availability of limited number of banks in the city of Bahawalpur and job holders having their salaries in government banks. These factors not accounted for in our research due to limited time frame and certain uncontrollable circumstances are some of the reasons which tended the customers to be loyal even due to non-provision and dissatisfaction from the level of trust they have on their banks. Loyalty creating factors are other independent variables of our research, especially satisfaction of the customers which is due to the the service quality on the other hand. Second objective is to identify which factor is the dominant variable that influences the customers to be loyal to their respective banks. Regression result shows that service quality has a significant positive influence on customer loyalty with positive beta value of 0.227 interpreting the contribution of customer satisfaction for more than 22 percent towards loyalty of the customers. To be loyal to a bank, customers will consider that how the restaurants are satisfying them through better quality services. If the banks are meeting their expectations about service quality the customers will be loyal to their banks. The results of this research could be beneficial for future researchers to better understand how the customer loyalty works, which is a part of consumer behavior. Besides, the results of this research are relatively important for other banks which presently are not functioning in Bahawalpur but intend to compete in this viable frame by creating customer loyalty followed by repeated 
purchase in future.

Despite Consumer behavior changes from time to time but if the banks are able to create loyalty in their customers, for sure it will generate financial benefits .Loyalty of the customer plays an important role for the success of any organization.

The managerial implication of this research are the considerations of bank managers for better, prompt and error free services having empathy for customers, personalized treatment of the customers, for customer satisfaction and their positive recommendation to others and also to build customer's trust in them.

\section{Limitations and Future Researches}

There are certain limitations of this study i-e Small sample size were selected from a limited geographical area and research is conducted in short span of time. The results of this research could be improved to expand it throughout the country and it is expected that the findings would not be significantly different. Also, the measurement trust was limited to 4 items. Even though these attributes were included in other studies and their validity is tested, there could be other relevant attributes that are likely to influence customers trust in financial institute.

\section{References}

Ali, J.F., I. Ali, U.K. Rehman, A.K. Yilmaz, N. Safwan and H. Afzal, 2010. Determinants of consumer retention in cellular industry of Pakistan. Afr. J. Bus. Manag., 4(12): 2402-2408

Aydin, S., \& Özer, G. (2005). The analysis of antecedents of customer loyalty in the Turkish mobile telecommunication market. European Journal of Marketing, 39(7/8), 910-925

Ball, D., Coelho, P.S.; \& Machas , A. (2004). The role of communication and trust in explaining customer loyalty an extension to the European Customer Satisfaction Index (ECSI) model, European.Journal of Marketing, 38(3), 1272-1293.

Barroso C. C. \& Martín A, E. (1999). Nivel de servicio y Retención de Clientes: El Caso de la BancaenEspana, Revista Espanola de Investigación de Marketing. ESIC, 3(1), 9-33.

Bloemer, J., De Ruyter, K. and Peeters, P. (1998). Investigating drivers of bank loyalty: the complex relationship between image, service quality and satisfaction", International Journal of Bank Marketing, Vol. 16 No. 7, pp. 276-86.

Brady, M. K., \& Cronin, J. J., Jr. (2001). Some new thoughts on conceptualizing perceived service quality and value. Journal of Consumer Research, 17(4), 375-384.

Bolton, R. N., \& Drew, J. H. (1991). A multistage model of customers' assessments of service quality and value. Journal of Consumer Research, 17(March), 375-384. http://dx.doi.org/10.1086/208564.

Chien, T. K., Chang, T. H., \& Su, C. T. (2003). Did your efforts really win customers satisfaction? Industrial Management and Data Systems, 103(4), 253-262.

Chaudhuri, A., \& Holbrook, M. (2001). The chain of effects from brand trust and brand effect to brand performance: the role of brand loyalty. Journal of Marketing, 65(4), 33-50

Cronin, J. J., \& Taylor, S. A. (1992).Measuring service quality: a re-examination and 
extension.Journal of Marketing, 56(July), 55-68. http://dx.doi.org/10.2307/1252296

Cronin, J.J., Brady, M.K., Hult, G.T.M., 2000. Assessing the effects of quality, value, and customer satisfaction on consumer behavioral intentions in service environments. Journal of Retailing 76 (2), 193-218.

De Ruyter, K., Wetzels, M. \& Bloemer, J. (1998). The relationship between perceived service quality, service loyalty and switching costs. International Journal of Service Industry Management, 9(5), 436-453.

Duffy, D.L. (1998). Customer loyalty strategies. Journal of Consumer Marketing, 15(5), 435-448

Fornell, C. (1992). A national customer satisfaction barometer: the Swedish experience. J. Mark., 56, 6-21

Gerpott, T. J., Rams, W., \& Schindler, A. (2001). Customer retention, loyalty and satisfaction in the German mobile cellular telecommunications market. Telecommunications Policy, 25(4), 249-269.

Gronroos, C. (1984). A service quality model and its marketing implications. European Journal of Marketing, 18(4), 36-44.

Heskett, J. L., Jones, T., Loveman, G., Sasser, W., \& Schlesinger, L. (1994), Putting the service profit chain to work, Harvard Business Review, 105-111.

Hocutt, M.A. (1998). Relationship Dissolution Model: Antecedents of Relationship Commitment and the Likelihood of Dissolving a Relationship, International Journal of Service Industry Management, 9(2), 189-200.

Hreinian, L.G. (1974). Effect of job level and anticipation on employee attitudes and perceptions of influence. Academy of Management Journal, 17, 649-662.

Johnson. M. D. \& Fornell. C. (1991). A Framework for Comparing Customer Satisfaction across Individuals and Product Categories. Journal of Economic Psychology 12, 267-286.

Khokhar, S.Z., F. Hussain, T.M. Qureshi, I. Anjum, A. Samran and R. Arshad, 2011. Only customer satisfaction and customer loyalty is not enough: A study of Pakistan's telecom sector. Afr. J. Bus. Manag., 5(24): 10176-10181

Larsson, S., \& Hjalte, S. ( 2004 ). Managing customer loyalty in the automobile industry. Ph.D. Lulea University of Technology. Sweden

Lee, H. S. (2010a). Effects of perceived value and service quality on customer satisfaction in the mobile phone service market. INFORMATION: An International Interdisciplinary Journal, 13(4), 1207-1218.

Liang, C.J., \& Wang, W.H. (2006). The behavioural sequence of the financial services industry in Taiwan - service quality, relationship quality and behavioural loyalty, The Services Industries Journal, 26(2), 119-45.

Maiyaki, A.A., N.B. Noor and S.S. Mokhtar, 2011. The influence of service quality of mobile phone on customer satisfaction in Malaysia: A students' feedback survey. J. Bus. Manag. Account., 1(1):79-97. 


\section{Al Macrothink}

International Journal of Accounting and Financial Reporting ISSN 2162-3082 2015, Vol. 5, No. 1

McIlroy, A. \& Barnet S. 2000. Building Customer Relationships: Do discount cards work? Mana-ging Service Quality, 10(6): 347-55.

Metters, R., King-Metters, K., \& Pullman, M. (2003).Successful Service Operations Management. Thomson South-Western. www.ccsenet.org/ass Asian Social Science Vol. 9, No. 2; 2013

Moorman, C., Deshpande, R. \& Zaltman, G. (1993). Factors affecting trust in market research relationships. Journal of Marketing, 57(1), 81-101.

Morgan, R.M, \& Hunt, S.D., (1994). The commitment - trust theory of relationship marketing. Journal of Marketing, 53(3), 20.

Oliver, R.L. (1997). Loyalty and profit: long - term effects of satisfaction, satisfaction: A behavioural perspective on the Consumer, MC Graw - Hill Companies, Inc., New York, NY

Oliver \& Richard, L. (1999). Whence Consumer Loyalty? Journal of Marketing, 63(4), $33-44$.

Phillips, D.M. \& Hans, B. (2002). The Role of Consumption Emotions in the Satisfaction Response, Journal of Consumer Psychology, 12(3), 243-52.

Parasuraman, A., Zeithaml, V. A. \& Berry, L. L. (1988). SERVQUAL: A multiple-item scale for measuring consumer perceptions of service quality. Journal of Retailing, 64 (1), 14-40.

Reichheld, F. F. (1993). Loyalty-Based Management. Harvard Business Review, 71(2), 64-73.

Rust, R. T., \& Zahorik, A. J. (1993). Customer satisfaction, customer retention, and market share. J. Retail. Summer, 69, 193-215.

Schurr, P. H. \& Ozanne, J. L. (1985). Influences on exchange processes buyers' preconceptions of a seller's trustworthiness and bargaining toughness, Journal of Consumer Research, 11(3), 939-953

Sheth, J., \& Parvatiyar, A. (1995). Relationship marketing in consumer markets: antecedents and consequences, Journal of the Academy of Marketing Science, 23(4), 255-271.

Shoemaker, S., \& Lewis, R.C. 1999, Customer Loyalty: The Future of Hospitality Marketing. Hospitality Management, 18(4): $345-370$.

Taylor, S. A., \& Baker, T. L. (1994). An assessment of the relationship between service quality and customer satisfaction in the formation of customers' purchase intentions. Journal of Marketing, 58(Summer), 163-178.

Westbrook, Robert A. and Richard L. Oliver (1991). The Dimensionality of Consumption Emotion Patterns and Consumer Satisfactions, Journal of Consumer Research, 18(1), 84-91.

Woodruff, R. B. (1997). Customer value: The next source of competitive advantage. Journal of the Academy of Marketing Science, 25, 139-153

Zeithaml, V. A., Berry, L. L., \& Parasuraman, A. (1996). The behavioral consequences of service quality. J. Mark., 60(2), 31-46. 